$10-8-2021$

\title{
Book Review: Integrations: The Struggle for Racial Equality and Civic Renewal in Public Education
}

Michael A. Ready

Gratz College

Follow this and additional works at: https://digitalcommons.usf.edu/gsp

\section{Recommended Citation}

Ready, Michael A. (2021) "Book Review: Integrations: The Struggle for Racial Equality and Civic Renewal in Public Education," Genocide Studies and Prevention: An International Journal: Vol. 15: Iss. 2: 58-60.

DOI:

https://doi.org/10.5038/1911-9933.15.2.1856

Available at: https://digitalcommons.usf.edu/gsp/vol15/iss2/10

This Book Review is brought to you for free and open access by the Open Access Journals at Digital Commons @ University of South Florida. It has been accepted for inclusion in Genocide Studies and Prevention: An International Journal by an authorized editor of Digital Commons @ University of South Florida. For more information, please contact digitalcommons@usf.edu. 
Book Review: Integrations: The Struggle for Racial Equality and Civic Renewal in Public Education

\section{Acknowledgements}

I would like to acknowledge my professors and colleagues at Gratz College, and in all public schools working to fight for equity and equality for all students. 


\title{
Book Review: Integrations: The Struggle for Racial Equality and Civic Renewal in Public Education
}

\author{
Michael A. Ready \\ Gratz College \\ Melrose Park, Pennsylvania, U.S.A.
}

Integrations: The Struggle for Racial Equality and Civic Renewal in Public Education

Lawrence Blum and Zoë Burkholder

Chicago and London, The University of Chicago Press, 2021

268 Pages; Price: $\$ 27.50$ Paperback

Reviewed by Michael Ready

Gratz College

In their illuminating, timely, and forward-thinking new book-Integrations: The Struggle for Racial Equality and Civic Renewal in Public Education-Lawrence Blum and Zoë Burkholder investigate the educational and moral consequences of United States' long history of school segregation. The book will be of interest to anyone in the field of Genocide Studies who is interested in parsing the multiple legacies of educational marginalization that the children of African American, Native American, Latinx, and Asian American communities have faced. And, perhaps more importantly, Integrations should be required reading for those of us in Genocide Studies who teach in the United States.

Blum and Burkholder make a kind of "dream team" author pairing, and this reviewer can think of no better set of co-authors for undertaking the task of this book. Blum is a distinguished professor of philosophy and one of the nation's leading voices on education, racism, and anti-racist pedagogies. Burkholder is a renowned historian of integration and racial justice in American schooling, who currently directs the Holocaust, Genocide, and Human Rights Education Project at Montclair State University. Together, they show that meaningful integration in American schooling requires Americans to think about integration itself in the plural sense- of finding ways of integrating white identities and narratives into the identities and narratives often attributed to "others," and embracing multiple histories and many possible definitions of and courses of action for integration.

Integrations focuses on the continued argument of racial and socio-economic disparities in American public education. The book can be divided into two main parts, each with central arguments and suggestions around an integrated and equal public education. The first two chapters sets up the historical precedence of racial and socio-economic inequalities in American public schools, while also establishing the main purpose of the institution. Public education in America, as Horace Mann stated in 1846, serves to provide a free education to all, "sufficient to qualify each citizen for the civil and social duties he will be called to discharge." 1 Public schools promised to forge a nation of immigrants into a united citizenry. Blum and Burkholder examine America's past educational policies and systems as methods of which white supremacy was instilled and maintained in the white mainstream political and social thought. With the Brown $v$. Board decision in 1954, explicit segregation, by which they define as meaning separation, was outlawed, and significant legal hurdles to unequal educational access was lifted. However, equal and equitable access to education was not rectified by this decision alone.

Blum and Burkholder spend the next three chapters of the book exploring the ways in which education has remained unequal, and potential ways to rectify this. At the center of their argument is that public education in America is based on fixed and often predetermined

\footnotetext{
${ }^{1}$ Lawrence Blum and Zoë Burkholder, Integrations: The Struggle for Racial Equality and Civic Renewal in Public Education (Chicago: The University of Chicago Press, 2021), 13.
}

Michael A. Ready. "Book Review: Integrations: The Struggle for Racial Equality and Civic Renewal in Public Education." Genocide Studies and Prevention 15, no. 2, 58-60. https://doi.org/10.5038/1911-9933.15.2.1856.

(C) 2021 Genocide Studies and Prevention. 
outcomes for all students. From the moment students enter the system, educators and administrators have made conclusions about these students based on a plethora of reasons, mainly socio-economic or racial in nature. Beyond this, American education is set up to produce a workforce and very little else. Thus, more affluent, often white middle-class students are awarded far better outcomes than that of people of color. Education is seen as a way to "achieve" something, generally academic accolades or tangible rewards. Integrations strongly refutes this approach to education, arguing that instead that quality education should be driven by four main factors: 1) intellectual/cognitive development (subject mastery and content knowledge), 2) Personal growth or individual flourishing (the formation of healthy friendships and the capacity to think and live a healthy life), 3) Moral capabilities (Possessing empathy, a sense of justice, and respect towards others), and finally 4) Civic Duty (commitment to engagement in ones polity, a commitment to the common good of all). ${ }^{2}$ These educational goods they outline make for the backbone of all their subsequent arguments and the ways that education should be driven to meet these goals.

The last two chapters outline the principals of integration that are commonly approached by educators and administrators, the first being based around capital, the other based around civic duty. In the first argument, Integrations explores the inherent problems with a capital approach to integration. While they acknowledge that many issues in public education stem from the lack of apparent capital in underserved communities, the approach to rectify this is often color-blind and harmful to non-white students. It equates to assimilationism, or the pressure put on a group to abandon a distinctive group identity and culture and adopt the norms and culture of the dominant group, i.e., middle-class white students. ${ }^{3}$ The idea surrounding this approach is that by assimilating poor communities into affluent ones, all students will benefit from the increased level of funds available. What this fails to realize is that in public education funds are never equally distributed. While some disadvantaged students may benefit from this, inherent tracking in school systems will most certainly maintain that students who have been labeled as underachievers or disadvantaged will more than likely stay as such. Secondly, it assumes that education can only be "fixed" with the capital gained by the advocacy of parents. White-middle class parents in this regard are more likely then to donate and provide funds for programs that aid their children (i.e., sports, advanced programs and the like). Another way to approach the Capital argument is by instead separating once again ethnoracial groups, so that funds can be pulled to service a single or several groups of under advantaged students based on their ethno-racial make-up. This approach maintains that by doing this, the color-blindness and inherent racism in the first approach is stalled. Blum and Burkholder refute this approach as well, arguing instead that by doing this, we lack the pluralism needed for a functioning democracy and it further delays anyways of addressing long standing inequalities and systemic racism in the school systems. Thus, they offer a second argument, integration based on civic duty.

They argue that only through integration with the mindset of creating, as Dr. King wrote, communities of equal respect, with the goal of meeting all of the educational goods outlined above. They argue that through egalitarian civic integrationist pluralism (ECIP) can truly equal and equitable education be reached. ${ }^{4}$ This includes integration of communities throughout the country, not by money or borders, but in spite of them. That curriculum needs to be active in bridging the gap between students and active in its portrayal of multiple perspectives and racial backgrounds. Educators need to be aware of their interactions with students as not to perpetuate the continued systems that have been in place. Growth mindset and restorative justice are imperative to making the civic approach a reality. Blum and Burkholder however acknowledge that schools alone cannot make this form of integration work. That in order for civic integration to be possible, legislators, educators, students, parents,

\footnotetext{
2 Ibid., 96.

${ }^{3}$ Ibid., 132.

${ }^{4}$ Ibid., 180 .
} 
and communities must come together and address the socio-economic disparities and systemic racism that plagues not just education but almost all social institutions.

Integrations is an integral look into the history and continued segregation of American schools in the post Brown v. Board era. In many ways, it explores how the American school system, which should be a backbone of our democracy and pluralistic society, has instead been used to prop up and maintain genocidal policies and racism since its inception. As we see time and time again, education is the cornerstone to both liberation and repression. Left to the wrong powers that be, education has been used to maintain systems of oppression and death for centuries. If we look at other examples of genocidal nations, we see a perplexing number of educators who collaborated with the systems that lead to mass murder. Pol Pot of Cambodia was a history teacher before he led Khmer Rouge in the murder of millions. In Nazi Germany, roughly ninety percent of all public school and university teachers were active members in the Nazi Party. Integrations if for no other reason than knowledge, should be commonplace on an educator's shelf. It encourages self-reflection and thought as we all approach our profession.

I am an educator in a small rural school in Washington state. My district services a predominantly white affluent community. Up until this year, we had allowed hate symbols such as the Confederate flag on our campus. Hate speech and vandalism was met with minor consequence and no school wide conversations. I understand the fear that comes from having these tough conversations. I understand that emotions run high especially in the rural areas of America. Yet, rather than face these fears head on, and tackle ways that could make our school a more inclusive place, our district as with so many other rural districts relent to a growing mass of misinformed community members and parents. Blum and Burkholder ring true in every way that true change CANNOT come from educators and schools alone. There is too much at stake and too little support to make it happen. My like-minded educators are sadly in the minority in the many different areas of rural America. My school is on traditionally Native lands. We "honor" this by hosting a racial caricature of our mascot that the community defends with a vehement myth that it is in respect to the Native ancestors of the community. The current political and post-fact society we live in makes for a civic integration of education to be an uphill battle, but one we desperately need.

While integration alone will not create a perfect equal education it will bring us closer to a kind of civic education that can better prepare our students for life in a multiracial plural society. Inequalities will always exist, as is the sad nature of existence. Inequities will continue to plague our nation and world. But, by taking steps to civically integrate and engage our students we give the tools to change these inequalities and inequities. I still hold true to my heart as an educator that public education is meant to bridge the gaps of inequality and give all who walk through our halls and doors the ability to flourish no matter what. But serious change needs to come from all corners of our polity. Only then can the ideas outline in Integrations begin to bear fruit and see the dreams of all students made real. 